\title{
Program PetroCaribe sebagai Strategi Ekonomi Venezuela Era Presiden Nicolas Maduro
}

\author{
Debby Aurellia, Yasinta D. Febriana, dan N. Salaeh \\ Universitas Muhammadiyah Malang
}

\begin{abstract}
ABSTRAK
PetroCaribe merupakan sebuah organisasi minyak yang diprakarsai olehVenezueladengantujuanuntukmelakukandiplomasiekonomidanmengatasikrisisminyakyang terjadidinegaranya. Selainitu, PetroCaribejuga ditujukan untuk menyediakan minyak dengan harga murah baginegaranegara di kawasan Karibia. Penelitian ini bertujuan untuk mengetahui alasan di balik dipertahankannya PetroCaribe sebagai cara untuk mengatasi krisis ekonomi di negara Venezuela, dan pengaruh dari adanya PetroCaribe terhadap negara- negara di wilayah Karibia. Pendekatan yang digunakan dalam penelitian ini adalah teori liberal institusionalis, yang menganggap negara sebagai aktor rasional yang egois dalam mengoperasikan dunia internasional sehingga perjanjian tidak dapat ditegakkan secara hierarkis. Oleh sebab itu, organisasi internasional hanya dapat berekspektasi bahwa kerja sama dapat terjadi jika negara memiliki kepentingan yang sama. Di sinilah PetroCaribe berguna sebagai suatu organisasi yang mewadahi kerja sama negara Venezuela sebagai aktor utama dengan negara-negara Karibia di dalam bidang ekonomi. Metode yang digunakan dalam penelitian ini adalah kualitatif yang bersifat deskriptif.
\end{abstract}

Kata-kata kunci: Karibia, Minyak, PetroCaribe, Venezuela.

PetroCaribe is an oil organization initiated by Venezuela for countries in the Caribbean region as a mean to economic diplomacy and overcome the oil crisis within the country. Furthermore, PetroCaribe aims to provide oil to countries in the Caribbean at low prices. This study aims to find out the reasons behind the retention of PetroCaribe as a way to overcome the economic crisis in Venezuela, and the influence of the existence of PetroCaribe on countries in the Caribbean region. The approach used in this study is the liberal institutionalist theory, which regards the state as a selfish rational actor in operating internationally so that agreements cannot be enforced hierarchically. Therefore, international organizations can only expect cooperation to occur if the states have the same interests. This is where PetroCaribe become useful as a form of organization that accommodates the cooperation of the Venezuelan state as the main actor with Caribbean countries in the economic field. The method used in this study is qualitative and descriptive.

Keywords: Caribbean, Oil, PetroCaribe, Venezuela. 
Venezuela merupakan negara yang terletak di utara Amerika Selatan dan merupakan negara penghasil minyak yang cukup besar. Minyak merupakan komoditas utama Venezuela dan sektor minyak juga menjadi penyumbang utama devisa negara. Sumber daya minyak mentah di Venezuela ditemukan sekitar tahun 1913. Pada tahun 1920, sebagian besar produksi minyak dari Venezuela dikuasai oleh perusahaan asing sehingga pada tahun 1970-an sehingga ditetapkan nasionalisasi minyak. Ekspor minyak mendominasi 90 persen dari total keseluruhan ekspor Venezuela dan menyumbang 60 persen dari pendapatan pemerintah sehingga perekonomian Venezuela pada saat itu berkembang pesat dan berdampak pada nilai riil GDP yang positif.Pada awalnya, tepatnya pada 1970-an, perekonomian Venezuela cenderung meningkat. Namun, karena terjadinya penurunan harga minyak dunia, ekonomi Venezuela juga cenderung menurun dan dihadapkan dengan faktor politik yang juga tidak stabil. Titik yang memperburuk perekonomian Venezuela adalah krisis politik pada kepemimpinan Presiden Nicolas Maduro. Pada rezim Nicolas Maduro, pemerintah dianggap otoriter dan kontroversial. Maduro dituduh melakukan pelanggaran hak asasi manusia dan menggunakan lembaga peradilan dan pasukan keamanan untuk melawan para oposisi politik. Krisis dan keterpurukan ekonomi Venezuela juga mengakibatkan instabilitas ekonomi seperti hiperinflasi dan kurangnya barang konsumsi, yang berimbas pada kemiskinan dan kelaparan. Sebab dari hiperinflasi yang dialami oleh Venezuela meliputi rendahnya harga minyak dunia, penurunan produksi minyak yang dihasilkan oleh Venezuela, dan kesalahan regulasi pemerintah dalam pengelolaan ekonomi.

Krisis yang terjadi di Venezuela mengakibatkan permasalahanpermasalahan lainnya, seperti kekurangan dan kelangkaan bahan pokok untuk kehidupan sehari-hari. Selain itu, tingkat kesehatan juga semakin menurun seehingga tingkat kriminalitas di Venezuela semakin memprihatinkan. Permasalahan-permasalahan tersebut kemudian memicu kemarahan publik sehingga aksi demonstrasi tidak terbendung lagi. Hal tersebut semakin memperburuk keadaan dalam negeri Venezuela. Aksi demontrasi tersebut merupakan bentuk kekecewaan masyarakat Venezuela terhadap rezim Nicolas Maduro. Mereka menganggap bahwa krisis tersebut terjadi karena ketidakmampuan pemerintah dalam mengelola negara, khususnya dalam bidang ekonomi. Selain itu, juga ketidakmampuan pemerintah dalam menghadapi korupsi juga semakin memperburuk perekonomianVenezuela (Elinda 2017). 
Salah satu langkah yang diambil oleh pemerintah untuk mengatasi krisis ekonomi tersebut adalah melalui jalan diplomasi minyak yang dinamakan PetroCaribe. PetroCaribe merupakan bentuk diplomasi minyak yang dibuat oleh Presiden Hugo Chavez, pemimpin Venezuela yang menjabat dari tahun 1999 hingga 2013. Venezuela memeroleh manfaat dari ledakan harga minyak selama tahun 2000-an. Saat Presiden Hugo Chavez mulai berkuasa pada tahun 1999, harga minyak mencapai $\$ 10$ per barel. Harga minyak terus mengalami kenaikan selama tahun-tahun berikutnya, hingga mencapai \$133 per barel pada Juli 2008 (Restuccia 2018). PetroCaribe terbentuk pada tahun 2005, tepatnya tanggal 6 September, dan masih berlangsung hingga sekarang di bawah rezim Nicolas Maduro. PetroCaribe memiliki tujuan untuk meyediakan minyak ke negara-negara di Karibia, namun ditambah dengan harga yang murah terhadap para anggota dan dengan sistem pembayaran yang meringankan negara-negara pembeli. PetroCaribe meringankan negara-negara pembeli dengan sistem preferential payment, yang memungkinkan pembayaran yang diangsur. Selain itu juga terdapat sistem barter, yakni pembayaran yang dilakukan dengan menggunakan barang lain seperti hasil perkebunan, pertanian, maupun jasa dari tenaga kerja.

Namun beberapa tahun belakangan, keberadaan program PetroCaribe mulai dipertanyakan oleh pihak-pihak dalam negara-negara Karibia tersebut melihat krisis ekonomi yang terjadi di Venezuela saat ini. Hal ini dikarenakan PetroCaribe sangat berkaitan langsung dengan krisis ekonomi yang melanda Venezuela, di mana minyak merupakan komoditas unggulan dan utama dalam perekonomian nasional. Sistem pembayaran yang telah disepakati oleh negaranegara Karibia tersebut tentu sangat dipengaruhi dan terdampak oleh krisis yang terjadi. Meski demikian, hingga saat ini, program tersebut terus berjalan sehingga menarik perhatian dari oposisi di Venezuela maupun dari masyarakat internasional.

Keberadaan PetroCaribe juga diangkat menjadi isu dalam protesprotes yang terjadi karena masyarakat mulai memikirkan dan mempertanyakan keuntungan yang dapat diperoleh Venezuela dari PetroCaribe. Masyarakat Venezuela beranggapan bahwa sistem pembayaran khusus dalam PetroCaribe tersebut justru merugikan Venezuela, khususnya secara ekonomi, sehingga masyarakat meminta pemerintah untuk menghentikan pengiriman minyak ke wilayah Karibia. Berbagai tekanan publik untuk menghentikan program PetroCaribe tersebut memaksa pemerintah untuk mempertimbangkan ulang kebijakannya dan memberikan perhatian 
khusus. Meskipun mendapat berbagai tekanan yang datang dari berbagai pihak, nyatanya program PetroCaribe masih berjalan hingga saat ini. Walaupun sedang dalam masa krisis, pengiriman minyak tetap dilakukan ke negara-negara Karibia. Bahkan, pemerintah Venezuela yang saat ini dipimpin oleh Nicolas Maduro mendeklarasikan komitmennya dalam program PetroCaribe pada konferensi PetroCaribe tahun 2015 lalu sebagai upaya untuk meningkatkan solidaritas dengan negara-negara anggota. Hal yang menjadi perhatian penulis dalam tulisan ini adalah bagaimana PetroCaribe masih dipertahankan di tengah tekanan dari berbagai pihak, seperti masyarakat dan partai oposisi. Signifikansi PetroCaribe terletak pada argumen bahwa dengan tidak adanya PetroCaribe, situasi ini bahkan akan menjadi jauh lebih buruk. Harga minyak naik dua kali lipat dalam dua tahun sebelum PetroCaribe, kemudian melonjak menjadi \$ 140 selama tiga tahun berikutnya. Kebijakan Venezuela terhadap PetroCaribe ini seakan semakin menguatkan strategi ekonomi yang digunakan terhadap negaranegara di Karibia di tengah krisis ekonomi yang melanda negara mereka.

Perjanjian PetroCaribe memungkinkan Badan Usaha Milik Negara atau BUMN milik Venezuela, perusahaan minyak Petroleos de Venezuela atau PDVSA, untuk menjual produk minyak mentah ke perusahaan-perusahaan dari negara-negara anggota PetroCaribe dengan persyaratan kredit preferensial. Kredit yang dimaksud adalah negara-negara penerima memiliki hingga 25 tahun untuk membayar kembali biaya pembelian, dengan tingkat bunga 2 persen apabila harga minyak di bawah US \$ 40 dolar per barel dan 1 persen apabila harga lebih tinggi. Negara-negara anggota PetroCaribe juga menerima produk dengan pembiayaan 40 persen apabila harga berada di atas US \$ 50 dolar per barel, 50 persen jika sudah di atas $\$$ 80 per barel, dan 60 persen jika mencapai $\$ 100$ per barel atau lebih (The Carribean Council 2014).

\section{Metode Penelitian}

Dalam tulisan ini, penulis menggunakan metode penelitian deskriptif analisis dengan menggunakan pendekatan kualitatif. Metode ini dipilih dengan didasari oleh pertimbangan bahwa penulis ingin memfokuskan kajian pada dampak signifikan yang ditimbulkan PetroCaribe, sebagai bentuk kerja sama antara Venezuela dan negara-negara Karibia, terhadap krisis ekonomi yang sedang dialami oleh Venezuela saat ini. Metode penelitian memberikan gambaran 
rancangan penelitian. Metode penelitian meliputi prosedur dan langkah-langkah yang harus ditempuh, waktu penelitian, sumber data, dan dengan langkah apa data-data tersebut diperoleh, diolah, dan dianalisis sesuai dengan prosedur dan kebutuhan penelitian. Prosedur tersebut dibutuhkan untuk membuat suatu tulisan lebih mudah dipahami oleh pembaca.

Adapun metode kualitatif adalah suatu proses penelitian dan pemahaman yang menggunakan permasalahan-permasalahan sosial atau manusia sebagai objek (Suryana 2010). Metode penelitian kualitatif merupakan pendekatan atau penelusuran yang berupaya memeroleh makna. Jenis metode penelitian kualitatif lebih menekankan pada penggunaan logika berpikir yang induktif atau logika dengan pola pikir yang diawali dengan premis-premis khusus dan mengarah pada premis umum melalui generalisasi (Creswell 2014). Sementara itu, menurut Nana Syaodih Sukmadinata (2011), penelitian yang bersifat deskriptif kualitatif bertujuan untuk mendeskripsikan atau menggambarkan suatu isu atau fenomena yang telah terjadi, baik fenomena-fenomena yang merupakan hasil rekayasa manusia maupun yang bersifat alamiah. Metode penelitian atau penulisan yang bersifat deskriptif kualitatif juga menekankan pada deskripsi suatu fenomena dengan apa adanya dan dengan data yang tidak direkayasa. Peneliti atau penulis hanya melakukan observasi dan mendokumentasikan data yang telah diperoleh tanpa mengubahnya sedikitpun (Sukmadinata 2011).

Dari apa yang telah dikemukakan oleh beberapa pakar di atas, maka dapat diketahui bahwa metode penelitian deskriptif kualitatif adalah serangkaian kegiatan yang bertujuan untuk memeroleh data yang bersifat apa adanya dan menekankan pada pemaknaan dari data yang telah diperoleh. Maka dari itu, fungsi metode deskriptif kualitatif yang dipilih dan digunakan oleh penulis adalah untuk menggali fenomena kerja sama PetroCaribe dengan pemaknaan dari penulis atas data yang diperoleh, sehingga para pembaca akan lebih mengetahui makna yang tersirat dari perjanjian internasional dan hubungan bilateral antarnegara. Dengan demikian, pembaca akan lebih memahami dan lebih kritis terhadap fenomena internasional yang terjadi saat ini. Selain itu, metode penelitian atau penulisan deskriptif kualitatif ini juga mampu membantu peneliti dalam melihat upaya dari Pemerintah Venezuela dalam program PetroCaribe tersebut sebagai langkah strategis bagi perekonomian negara tersebut, serta dalam menganalisis dampak yang ditimbulkan oleh kerja sama perjanjian tersebut. 
Adapun teknik pengumpulan data dalam tulisan ini adalah dokumentasi, yakni suatu teknik pengumpulan data melalui pengumpulan data-data yang diperlukan untuk memperkuat argumen dan hipotesis yang diangkat dan dianggap menarik oleh penulis. Dengan demikian, hipotesis dan argumen yang telah dipaparkan menjadi lebih akurat, kuat, serta bisa dipercaya dan diterima oleh pembaca maupun khalayak umum. Dokumen atau data yang dipaparkan oleh penulis diperoleh dari dokumen primer, sehingga data yang diperoleh memiliki tingkat akurasi tinggi dan dapat dipertanggung jawabkan. Selain dokumen primer, penulis juga menambahkan data sekunder yang diakses dari situs-situs berita resmi dan beberapa situs sekunder milik individu untuk menjadi bahan bacaan serta memperkuat hipotesis penulis mengenai isu yang diangkat.

Basic research atau tujuan dari penulisan ini adalah untuk melakukan verifikasi, yakni kegiatan penelitian yang dilakukan dengan tujuan untuk menguji atau membuktikan kebenaran dari pengetahuan yang telah ada sebelumnya. Penulis melakukan penelitianini untuk membuktikan kebenaran dari teori Liberal Institusionalis dengan mengaplikasikannya pada analisis mengenai kepentingan ekonomi Venezuela dalam PetroCaribe.

\section{Tinjauan Pustaka}

PetroCaribe merupakan bentuk diplomasi minyak yang diprakarsai oleh Venezuela, lebih tepatnya oleh mantan presiden Hugo Chavez yang memimpin Venezuela dari tahun 1999 hingga tahun 2013. PetroCaribe ini dibentuk pada tanggal 6 September 2005 dan digunakan sebagai sarana bagi negara-negara di Karibia yang ingin membeli minyak mentah dengan menyediakan kredit dengan harga murah. PetroCaribe terus dilanjutkan oleh Presiden Nicolas Maduro, yang berkuasa dari tahun 2013 hingga sekarang. Program ini memiliki tujuan untuk menyediakan minyak bagi negara-negara di kawasan Karibia dengan harga yang murah dan sistem pembayaran yang meringankan negara pembeli (Lai 2006). Negara-negara yang membeli minyak dari Venezuela dapat menyicil pembayaran di muka dari 30\% hingga 95\%. Sisa dari pembayaran dapat dibayar dengan jangka waktu sangat lama, berkisar dari 17-25 tahun, dan dengan suku bunga 1-2 persen.

Tujuan pembentukan PetroCaribe adalah sebagai bentuk kerjasama dan komplementaritas energi yang didasarkan pada dua pilar. Pilar yang pertama adalah membangun solidaritas antara negara yang me- 
miliki sumber daya energi yang berlebih, seperti Venezuela, dengan negara-negara yang tidak memiliki sumber daya energi yang cukup. Pilar yang kedua adalah pengakuan akan adanya asimetri antara negara seperti Venezuela, yang memiliki tingkat pembangunan ekonomi yang relatif menengah, dan negara-negara anggota lainnya yang memiliki tingkat pembangunan yang lebih rendah (SELA 2015). PetroCaribe menyediakan anggaran jangka pendek bagi negara-negara penerima yang sedang menghadapi masalah fiskal yang parah, seperti ketika harga minyak dapat menjadi $\$ 100$ per barel. Pada tahun 2012, ketika harga minyak rata-rata melebihi $\$ 111$ per barel, ekspor PetroCaribe memuncak hingga $\$ 121.000$ barel per hari. Bagaimanapun, program ini juga secara signifikan meningkatkan keseluruhan hutang negara penerima. Kesepakatan dari pembelian minyak dalam PetroCaribe berfungsi dengan cara diskon, di mana negara-negara kontraktor diharuskan membayar persentase dari harga pasar. Sisa biaya kemudian dikonversi menjadi pinjaman jangka dan berbunga rendah seperti yang telah dijelaskan diatas. Di sisi lain, ketergantungan negara penerima terhadap PetroCaribe telah mengikis kebebasan mereka dalam berpolitik. Meski demikian, data yang ada menunjukkan bahwa selama 10 tahun sejak dijalankannya program PetroCaribe, setidaknya $32 \%$ permintaan akan kebutuhan energi minyak di negara anggota dapat terpenuhi (SELA 2015).

Venezuela sering dianggap menggunakan PetroCaribe untuk menyebarkan pengaruh ke Organisasi Amerika Serikat atau OAS. Di tengah krisis ekonomi dan inflasi besar-besaran yang terjadi di Venezuela, negara tersebut masih memegang predikat sebagai negara penghasil minyak terbesar di dunia, yang terlihat dari banyaknya cadangan minyak yang dimiliki. PetroCaribe menjadi salah satu alat bagi Venezuela, khususnya Presiden Nicolas Maduro, dalam menarik dukungan dari negara - negara di Karibia. PetroCaribe juga memungkinkan Venezuela untuk memainkan peran dominan dalam OAS.Negara-negara anggota dari PetroCaribe meliputi negaranegara Carribean Community (Caricom), yaitu organisasi negaranegara Karibia yang memiliki tujuan utama untuk mempromosikan integrasi ekonomi dan kerjasama di antara anggotanya, menjamin bahwa keuntungan integrasi regional dinikmati bersama, dan mengkoordinasikan kebijakan luar negeri. Aktivitas utama organisasi ini meliputi koordinasi kebijakan ekonomi dan perencanaan pembangunan, penyusunan proyek-proyek istimewa untuk negara kurang berkembang di dalam yurisdiksinya, operasi sebagai pasar regional bagi sebagian anggotanya dalam Caricom Single Market, 
mengoperasikan Caribbean Court of Justice atau CCJ yang berperan sebagai mahkamah akhir untuk banding bagi banyak anggota Caricom, dan menangani sengketa dagang regional. Carribean Community meliputi Antigua dan Barbuda, Bahama, Barbados, Belize, Dominika, Grenada, Guyana, Haiti, Jamaika, Montserrat, Saint Lucia, Saint Kitts dan Nevis, St. Vincent dan Grenadines, Suriname, serta Trinidad dan Tobago. Dari keseluruhan negara anggota Caricom, terdapat beberapa negara yang tidak tergabung sebagai negara anggota PetroCaribe, yakni Barbados serta Trinidad dan Tobago. Bagi Caricom, PetroCaribe merupakan tawaran terbaik yang telah disediakan. Hal ini dikarenakan oleh fakta bahwa bagi 13 negara Caricom-bersama dengan Kuba dan Republik Dominikayang telah menerimanya, PetroCaribe dapat menjadi jalan terbaik dari kesengsaraan yang mereka rasakan pada saat ini.

Pada tahun 2006, seperti yang dinyatakan oleh reporter terkenal Karibia Tony Best, PetroCaribe tidak menawarkan minyak murah, karena kewajiban Venezuela terhadap OPEC melarangnya untuk melakukan penjualan di bawah nilai pasar. Sebagai gantinya, pendekatan inovatif yang digunakan memungkinan negara-negara kawasan untuk menunda pembayaran (Lai 2006). Selain itu, hutang negara-negara Karibia ini dapat diamortisasi secara parsial dengan cara membayar atau menukarnya dengan barang dan jasa. Negara anggota dapat membayar Venezuela dengan hasil pertanian dan perkebunan, seperti tebu, beras, pisang, maupun bentuk-bentuk jasa seperti tenaga medis (Jacome 2011). Sebagai contoh, Venezuela dan Kuba mencanangkan program yang dikenal sebagai "Oil for Doctors", di mana Kuba mengirim lebih dari sepuluh ribu dokter, perawat, dan dokter gigi untuk memberikan perawatan kesehatan gratis bagi komunitas termiskin yang ada di Venezuela, dengan imbalan 90.00o barel minyak Venezuela per hari. Di bawah perjanjian tersebut, Venezuela akan menanggung biaya pengiriman, bantuan dalam pengembangan infrastruktur distribusi dan situs penyimpanan, berkontribusi pada pembentukan fasilitas yang dikontrol negara, dan menyediakan sistem hemat bahan bakar di negara-negara anggota.

Perjanjian PetroCaribe didasarkan pada penghapusan semua perantara, sehingga PetroCaribe hanya akan berurusan dengan entitas yang dikendalikan negara. Tujuan dari hal tersebut adalah untuk mengurangi biaya perantara yang tidak perlu. Ini berarti bahwa distributor area AS yang ada, yakni Shell dan Texaco, akan dikeluarkan dari pembelian minyak Venezuela yang bersubsidi di bawah program tersebut. Akibatnya, negara-negara Caricom yang 
berpartisipasi akan beralih ke arah de-privatisasi infrastruktur industri minyak mereka demi mendirikan fasilitas yang dipandu negara. Delapan belas negara di Karibia kini berpartisipasi dalam program ini, dan Menteri Perminyakan Venezuela Rafael Ramirez memperkirakan bahwa pada tahun 2011 PetroCaribe mencakup 43 persen dari kebutuhan energi negara-negara peserta. Adanya PetroCaribe telah banyak membantu negara-negara Karibia dalam memenuhi kebutuhan energi. Minyak yang dikirim ke negara-negara Karibia mencapai rata-rata 250.00o barel per hari sejak tahun 2006 hingga 2014 (seeking Alpha 2014). Negara-negara yang menjadi anggota menerima jumlah yang berbeda tergantung pada perjanjian yang telah disepakati, dan tentunya membayar dengan sistem pembayaran yang dimudahkan.

Pinjaman yang diberlakukan oleh Venezuela terhadap negara-negara di Karibia dalam PetroCaribe ini dapat dikatakan sebagai pinjaman lunak. Pinjaman lunak masih merupakan pinjaman yang harus dibayar kembali, namun PetroCaribe setidaknya memungkinkan negara-negara yang berpartisipasi untuk bisa sedikit terbebas dari beban. Negara-negara tersebut dengan demikian dapat menyusun strategi pembangunan yang tepat tanpa harus mengkhawatirkan penagihan hutang. Bahkan, pada kenyataannya hutang pada PetroCaribe memberikan manfaat sampingan bagi mereka yang meneken kontrak. Pada sisi lain, bagaimanapun, masyarakat mempertanyakan alasan pemerintah mempertahankan program PetroCaribe. Keraguan rakyat Venezuela terhadap PetroCaribe tersebut tercermin dari beberapa demonstrasi yang dilakukan di Caracas (Patilla 2015). Dalam demonstrasi tersebut, publik mempertanyakan keuntungan ekonomi yang diperoleh rakyat Venezuela dari PetroCaribe serta menuntut pemerintah untuk tidak meneruskan pengiriman minyak ke negara-negara anggota PetroCaribe, karena program pengiriman minyak dengan sistem pembayaran khusus tersebut dianggap membebani perekonomian Venezuela khususnya pada masa krisis.

Krisis ekonomi di Venezuela dimulai dari tahun 2014 dan belum dapat terselesaikan hingga sekarang. Krisis ekonomi tersebut ditandai dengan tingkat pertumbuhan ekonomi yang menurun dan terjadinya inflasi yang tinggi pada kurun waktu 2014 hingga sekarang. Berdasarkan laporan International Monetary Fund atau IMF yang dikutip oleh Borger (2016), dapat diketahui bahwa Produk Domestik Bruto atau PDB Venezuela menurun sejak tahun 2014 hingga tahun 2016, menunjukkan bahwa Venezuela memiliki tingkat pertumbuhan negatif dan terus menurun dalam jangka waktu tersebut. 


\section{Landasan Teori}

Pendekatan teori yang digunakan dalam penelitian ini adalah teori liberal institusionalis. Liberalisme memiliki tiga asumsi dasar, yakni: (1) pandangan positif tentang sifat manusia; (2) keyakinan bahwa hubungan internasional dapat bersifat kooperatif daripada konflik-tual; dan (3) kepercayaan terhadap kemajuan (Jackson dan Sorensen 2014). Salah satu asumsi dasar liberalisme adalah keyakinan terhadap kemajuan. John Locke beranggapan bahwa kemajuan menurut kaum liberal adalah kemajuan bagi individu yang mendapatkan jaminan kebebasan dari negara untuk melangsungkan kehidupannya dan menggapai kebahagiaannya tanpa ada campur tangan dari pihak lain. Sebagaimana yang dikatakan Keohane (1995 dalam Jackson dan Sorensen 2014), liberalisme pascaperang terbagi ke dalam empat aliran pemikiran utama, yaitu liberalisme sosiologis, liberalisme interpedensi, liberalisme institusional, dan liberalisme republikan.Kaum liberal institusionalis menganggap negara sebagai aktor rasional yang egois dalam mengoperasikan dunia internasional, sehingga perjanjian tidak dapat ditegakkan secara hirarkis. Oleh sebab itu, organisasi internasional hanya dapat berekspektasi bahwa kerja sama dapat terjadi jika negara-negara memiliki kepentingan yang sama. Menurut kaum liberal institusionalis, ketika negara tidak melihat manfaat dari adanya kerjasama, maka kerjasama tidak akan terjadi dan organisasi internasional yang memfasilitasi kerja sama tidak akan berkembang (Keohane 1995). Ketika negara saling memperoleh keuntungan, maka negara akan berusaha untuk membentuk organisasi. Organisasi ini kemudian berfungsi untuk menyediakan informasi, mengurangi biaya transaksi, membuat komitmen menjadi lebih kredibel, mendirikan titik fokus koordinasi, dan memfasilitasi hubungan respirokal. Oleh karenanya, negara secara sadar menggunakan organisasi internasional untuk mengurangi biaya transaksi, menciptakan informasi, ide, norma, dan ekspektasi. Tindakan dan perilaku suatu negara dalam organisasi internasional pada dasarnya bergantung pada selfinterest dan faktor-faktor lain yang memengaruhi keputusan negara tersebut. Keuntungan relatif menjadi salah satu faktor penting yang mendasari arah tindakan negara dalam organisasi internasional (Keohane 1995). Liberal institusionalisme berfokus pada persebaran informasi yang dapat memaksimalkan kebijakan, sehingga memiliki nilai guna yang tinggi dan bersifat aplikatif. 


\section{Hasil Temuan dan Pembahasan}

Pembuatan kebijakan yang dilakukan oleh Presiden Maduro berkaitan erat dengan arah kebijakan luar negeri yang dicanangkan oleh Chavez pada masa pemerintahannya. Walaupun dalam keadaan negara yang sedang mengalami krisis saat ini, dengan kemerosotan yang sangat drastis pada situasi politik dan keadaan ekonomi, Presiden Maduro masih berkeinginan kuat untuk menciptakan sistem multipolar di dunia. Hal ini dapat direalisasikan dengan menjalin solidaritas dan persahabatan antarnegara dengan program PetroCaribe ini. Program ini juga ditujukan untuk menyokong kekuatan Venezuela di sektor minyak, yang dapat mendukung perekonomiannya. Adapun relasi yang dimaksudkan adalah menjalin hubungan dengan negara-negara luar untuk menarik bantuan luar negeri, sebagai upaya untuk membangun dan menanggulangi krisis yang terjadi (Dewi 2016).

Keberadaan relasi tersebut juga akan menghentikan ketergantungan Venezuela terhadap Amerika Serikat, yang selama ini telah mendominasi perekonomian dan sistem internasional. Maduro berpandangan bahwa potensi yang dimiliki oleh kawasan Amerika Latin dapat menjadi senjata ampuh dalam perekonomian serta penyebaran ideologinya, sehingga kawasan Karibia yang merupakan pembatas antara Venezuela dan Amerika dapat menjadi jalan untuk merealisasikan kepentingan tersebut dalam bentuk organisasi kerja sama internasional. Hal ini merefleksikan asumsi dasar dari teori Liberal Institusionalis yang digunakan dalam kajian ini.

Seperti yang telah dituliskan sebelumnya, PetroCaribe didirikan untuk negara-negara Karibia, karena wilayah Karibia merupakan wilayah yang memiliki nilai strategis tersendiri. Nilai strategis ini terletak pada adanya keanggotaan Organization of American States (OAS). Dengan demikian, apabila Venezuela berhasil memeroleh dukungan negara-negara Karibia melalui PetroCaribe, maka secara otomatis Venezuela akan mendapat dukungan dari OAS. Negaranegara Karibia mencakup separuh dari total suara di OAS dan seluruhnya memiliki keanggotaan dalam PBB. Dalam penggunaan PetroCaribe oleh Venezuela, dapat diidentifikasi kepentingankepentingan politik dan ekonomi. Dalam aspek politik, dapat dilihat bahwa Venezuela berusaha melakukan penyebaran "newleft ideology", sedangkan dalam hal ekonomi terdapat kepentingan berupa pasar dan bantuan luar negeri.

"New-left ideology" yang dimaksud adalah ideologi Bolivarian, yang diambil dari nama figur nasionalis Simon Bolivar. Ideologi ini meng- 
hendaki beberapa poin: (1) tatanan dunia yang multipolar dan tidak didominasi oleh aktor-aktor hegemonik seperti Amerika Serikat; (2) penolakan terhadap kapitalisme yang selama ini dianut dan disebarkan oleh Barat, khususnya Amerika Serikat; (3) kerja sama antara negara-negara Selatan atau South-South cooperation, yang bersifat kooperatif dan mendukung integritas kawasan; (4) kerja sama antarnegara yang dilandasi oleh prinsip solidaritas internasional. Ideologi tersebut kemudian mengalami perkembangan dan ditambahkan dengan penggunaan kekuatan negara untuk menstimulasi pertumbuhan ekonomi dan memperbaiki kegagalan pasar, serta penggunaan kekuatan negara untuk ikut serta dalam organisasiorganisasi regional maupun internasional untuk memperbaiki kesenjangan sosial dalam sistem internasional dan meningkatkan partisipasi politik.

Selain penyebaran ideologi, terdapat pula kepentingan ekonomi yang menjadi alasan kuat dari dipertahankannya PetroCaribe. Pada dasarnya, sentralitas fungsi minyak dalam PetroCaribe memiliki dua poin penting. Pertama, PetroCaribe berdampak positif terhadap indeks komulatif yang mencapai angka puluhan miliar, dengan transaksi yang lebih banyak menggunakan valuta asing. Kedua, penghentian PetroCaribe akan memberikan dampak yang lebih buruk terhadap perekonomian Venezuela (Cusack 2014). Sistem pembayaran yang dapat diangsur dalam PetroCaribe dapat berubahubah mengikuti harga minyak dunia. Hal ini memberikan potensi keuntungan yang lebih besar dan berlipat ganda bagi Venezuela. Selain itu, sistem barter pada proses transaksi dalam PetroCaribe berfungsi sebagai upaya pemerintah dalam menangani krisis yang ada, yakni permasalahan-permasalahan sosial seperti kemiskinan, kelaparan, dan penyakit sebagai dampak dari hiperinflasi yang terjadi. Oleh karena itu, Venezuela memerlukan bahan pokok untuk keberlangsungan hidup masyarakatnya.

Dengan demikian, di balik adanya pro-kontra dalam kebijakan Venezuela untuk mempertahankan PetroCaribe, tentu saja krisis ekonomi yang dialami oleh Venezuela memiliki pengaruh yang besar bagi stabilitas wilayah Karibia, sehingga krisis Venezuela dapat dikatakan sebagai krisis ekonomi global yang menjadi perhatian internasional. Pengambilan sikap tertutup oleh pemerintah Venezuela terhadap dunia luar juga telah memperburuk kondisi ekonomi negara itu sendiri, sehingga diperlukan diplomasi ekonomi yang signifikan dan intens dengan negara-negara lain. Dalam setiap perjanjian, termasuk PetroCaribe, setiap negara memiliki kepentingan-khususnya kepentingan ekonomi-yang harus dicapai. 
Hal tersebut dibenarkan oleh teori Liberal Institusionalis, yang beranggapan bahwa untuk mencapai kekayaan, negara selalu meningkatkan intensitas hubungannya dengan dunia luar. Peningkatan intensitas hubungan ini dapat dilihat pada pelaksanaan PetroCaribe oleh pemerintah Venezuela, yang merupakan langkah strategis bagi perekonomian negara tersebut.

Penurunan egoisme atau tendensi isolasionis suatu negara merupakan hal yang penting untuk dilakukan, mengingat adanya interdependensi kompleks antarnegara saat ini. Hal ini berarti bahwa setiap negara memerlukan negara lainnya, baik secara ekonomi, sosial, maupun politik. Dalam konteks demikian, hubungan antarnegara yang baik akan tercipta ketika setiap negara memiliki power atau potensi yang berbeda-beda. Hal ini dapat dilihat pada perilaku Venezuela yang memanfaatkan sumber alam minyaknya sebagai alat untuk mencapai tujuan ekonominya. Bagaimanapun, ketika negara tidak mampu menentukan strategi yang tepat untuk melaksanakan kepentingannya, maka power tersebut akan sia-sia dan tidak dapat digunakan secara efektif. Sebaliknya, ketika power atau sumber daya yang dimiliki suatu negara digunakan dengan strategi yang tepat, maka power atau sumber daya tersebut akan menjadi suatu kekuatan baru bagi negara tersebut.

\section{Kesimpulan}

Venezuela merupakan negara yang menempatkan komoditas minyak sebagai sumber pendapatan utamanya. Ketergantungan yang tinggi terhadap minyak membuat perekonomian negara Venezuela bergantung pada harga minyak dunia. Ketika harga minyak dunia berada di puncak, maka ekonomi Venezuela akan mengalami ekspansi yang tajam. Hal ini berarti terdapat peluang yang tinggi dari fenomena tersebut bagi perekonomian Venezuela. Bagaimanapun, potensi dari pemerolehan kekayaan melalui ekspor minyak tidak mendorong pemerintah Venezuela untuk memanfaatkannya bahkankejadian yang terjadi pada tahun 1970-1980-an tidak memberikan pengalaman bagi Venezuela dalam menentukan kebijakannya. Ketika harga minyak sedang berada dalam masa boom, pemerintah lebih terfokus pada defsisit anggaran-atau penambahan hutang publik-untuk pembiayaan sosial dan tidak menggunakannya untuk meningkatkan cadangan devisa.

Pengambilan langkah yang salah tersebut merupakan akibat dari tindakan spekulasi oleh pemerintah Venezuela, yang beranggapan bahwa harga minyak akan terus mengalami kenaikan. Nyatanya, 
harga minyak dunia sangat fluktuatif. Hal ini dapat dibuktikan dengan fakta bahwa hingga tahun 2014, harga minyak dunia kembali mengalami penurunan sehingga cadangan devisa Venezuela yang sedikit tidak dapat menutupi pembayaran hutang. Krisis yang menimpa Venezuela diakibatkan oleh kebijakan pemerintah yang tidak mampu memanfaatkan potensi dari perdagangan minyak ketika minyak dunia berada pada harga puncak. Penyaluran dana terlalu difokuskan pada program-program yang tidak produktif dan cenderung tidak berkelanjutan. Selain itu, unsur politik seperti program nasionalisasi Venezuela dan sentimen anti-asing juga memperburuk kondisi perekonomian Venezuela. Di era perekonomian terbuka seperti saat ini, dengan intensitas perdagangan internasional yang semakin tinggi, pemaksaan unsur ideologis dan politik dalam kebijakan ekonomi merupakan hal yang kurang tepat untuk dilakukan. Hal tersebut merupakan faktor utama yang memperparah kondisi di Venezuela hingga saat ini. Adapun langkah yang harus diambil oleh pemerintah adalah memfokuskan pada penyelesaian masalah ekonomi terlebih dahulu sebelum mengupayakan penyebaran ideologi kiri yang direncanakan melalui program Petrocaribe. 


\section{Daftar Pustaka}

\section{Buku dan Bab dalam Buku}

Creswell, J. W., 2014. Research Design: Qualitative, Quantitative, and Mixed Methods Approaches, 4th edition. Thousand Oaks: SAGE Publications.

Jackson, Robert, dan Georg Sorensen, 2014. Pengantar Studi Hubungan Internasional: Teori \& Pendekatan, edisi kelima (trans. Dadan Suryadipura, Introduction to International Relations, $5^{\text {th }}$ edition). Yogyakarta: Pustaka Pelajar.

Sukmadinata, N. S., 2011. Metode Penelitian Pendidikan. Bandung: Remaja Rosdakarya.

Suryana, 2010. Metodologi Penelitian: Model Praktis Penelitian Kuantitatif dan Kualitatif. Sumedang: Universitas Pendidikan Indonesia.

\section{Artikel Jurnal}

Cusack, A. K., 2014. "Protests, Polarisation, and Instability in Venezuela”, Carribean Journal of International Relations \& Diplomacy, 2(1): 99-111.

Elinda, S., 2017. "Alasan Tetap dipertahankannya Program PetroCaribe di Wilayah Karibia”, Jurnal Analisis Hubungan Internasional, 6(3): 119-38.

Jacome, F., 2011. "Petrocaribe: The Current Phase of Venezuela's Oil Diplomacy in The Carribean.”. Programa de Cooperacion en Seguridad Regional, Policy Paper 40: 1-10.

Razali, R., 2014. "Analisis Penerapan Kebijakan Ekonomi Sosialis Venezuela pada Masa Pemerintahan Hugo Chavez Menghadapi Imperialisme Ekonomi”, Jurnal Online Mahasiswa, 1(2): 1-9.

Keohane, Robert O., 1995. "The Promise of Institutionalist Theory“, International Security, 20(1): 39-51. 


\section{Laporan Penelitian}

Dewi, W. C., 2016. Strategi Kebijakan Nicolas Maduro dalam Mempertahankan Stabilitas Politik di Venezuela Pasca Chavez Periode 2013-2016. Skripsi. Surakarta: Departemen Hubungan Internasional Fakultas Ilmu Sosial dan Ilmu Politik Universitas Sebelas Maret.

Firdaus, F., 2017. Strategi Perlawanan Venezuela dalam Menghadapi Tekanan Amerika Melalui ALBA Tahun 2015-2017. Skripsi. Surabaya: Departemen Hubungan Internasional Fakultas Ilmu Sosial dan Ilmu Politik Universitas Airlangga.

\section{Laporan Tahunan}

SELA, 2015. Evolution of The Petrocaribe Energy of the Cooperation Agreement.

\section{Artikel Online}

Lai, K., 2006. "PetroCaribe : Chavez's Venturesome Solution to the Carribean Oil Crisis" [online]. dalam https://venezuelanalysis.com/analysis/1592 [diakses 16 Desember 2016].

The Carribean Council, 2014. "Venezuela: instability and the impact of potential changes to the PetroCaribe scheme on the Caribbean Basin" [online]. dalam https://www.caribbean-council.org/venezuela-instabilityimpact-potential-changes-petrocaribe-scheme-caribbeanbasin/ [diakses 17 Mei 2019]. 